\title{
BACTERIAL CELLULOSE FROM RICE WASTE WATER AND ITS COMPOSITE WHICH ARE DEPOSITED NANOPARTICLE AS AN ANTIMICROBIAL MATERIAL
}

\author{
Eli Rohaeti ${ }^{a^{*}}$, Endang W Laksono ${ }^{a}$, and Anna Rakhmawati ${ }^{\mathrm{b}}$ \\ ${ }^{a}$ Chemistry Department, Faculty of Mathematics and Natural Science, Yogyakarta State \\ University, Indonesia \\ ${ }^{b}$ Biology Education Department, Faculty of Mathematics and Natural Science, Yogyakarta \\ State University, Indonesia \\ *email : eli_rohaeti@uny.ac.id; rohaetieli@yahoo.com \\ DOI : 10.20961/alchemy.v12i1.946 \\ Received 02 February 2016, Accepted 24 February 2016, Published 01 March 2016
}

\begin{abstract}
Bacterial cellulose $(\mathrm{C})$ and its composites were synthesized from rice waste water with addition of glycerol $(\mathrm{G})$ and chitosan $(\mathrm{Ch})$. Antibacterial activity of the $\mathrm{C}$, the bacterial cellulose-chitosan composite $(\mathrm{CCh})$, and the bacterial cellulose - glycerol chitosan composite (CGCh) which were deposited silver nanoparticles against $S$. aureus, $E$. coli, and yeast $C$. albicans has been conducted. Silver nanoparticles was prepared by chemical reduction of a silver nitrate solution, a trisodium citrate as a reductor, and a PVA as a stabilizer. The UV-Vis spectroscopy is used to determine the formation of silver nanoparticles. The characterization was conducted on the bacterial celluloses and those composites including the functional groups by the FTIR, the mechanical properties by Tensile Tester, photos surfaces by SEM, and the test of the antibacterial activity against $S$. aureus, E. coli, and C. albicans by diffusion method. The silver nanoparticle characterization indicates that the silver nanoparticles are formed at a wavelength of $418.80 \mathrm{~nm}$. The antibacterial test showed an inhibitory effect of the $\mathrm{C}$, the $\mathrm{CCh}$, and the CGCh which are deposited the silver nanoparticles against of S. aureus, E. coli, and C.albicans. The CGChs which are deposited silver nanoparticles has the highest antimicrobial activity against the Staphylococcus aureus ATCC 25923. The CGs which are deposited silver nanoparticles provide the highest antimicrobial activity against the $E$. coli ATCC 25922 and the yeast Candida albicans ATCC 10231.
\end{abstract}

Keywords: antimicrobial, bacterial cellulose, chitosan, glycerol, and silver nanoparticle.

\section{INTRODUCTION}

Utilization of household waste as a medium for the formation of bacterial cellulose has not been widely studied. Thus doing research on the formation of bacterial cellulose from rice waste water is valuable. Rice waste water can be made into cellulose through the addition of sucrose, urea, and acetic acid (Hoenich, 2006). A cellulosic polymer is reinforced by XRD diffractogram, IR spectrum, thermal properties, and surface image by SEM (Ciechńska, 2004). A microorganism that can produce cellulose is an acetobacter. 
The acetobacter is the bacteria which is used to produce vinegar. When the vinegar production process takes place, often membrane that resembles a gel form films on the surface of the culture medium is found. This material is known as microbial cellulose. (Ciechńska, 2004; Morones et al., 2005; and Baker et al., 2005).

The bacterial cellulose can be used to treat patients with kidney failure and as a temporary skin substitute for treating burns. The cellulose can also be used as sewing threads and implanted into the human body in surgery (Heru and Eli, 2010). Some literature reveals that bacterial cellulose performed well enough to be used for wound healing in biomedical purposes. The bacterial cellulose has high hydrophilicity properties and can be used as an artificial blood vessel, non-allergenik, and can be sterilized without affecting the characteristics of the material (Heru and Eli, 2010; Philips and Williams, 2000). However, cellulose is an excellent medium for the growth of microorganisms, because the surface area is quite spacious and it is able to retain moisture. To overcome these problems, it has been composited by using silver compounds. The antimicrobial silver particles are influenced by particle size. The smaller the particle size, the greater the antimicrobial effect is generated. (Fang et al., 2005; Lina et al., 2011; Kuusipalo et al., 2005; and Anicuta et al., 2010). Silver nanoparticles are generally smaller than $100 \mathrm{~nm}$ and containing silver as much 20 - 15000 atom (Brugnerotto et al., 2001).

Their superior properties of microbial cellulose and chitosan may be made of a composite material that is experiencing the interaction between the molecules of chitosan (unit glucosamine and $\mathrm{N}$-acetylglucosamine) with the resulting cellulose chain. However, cellulose and chitosan are media for the growth of microorganisms, because their surface area are quite spacious and they are able to retain moisture. To overcome these problems, many of the chemicals that have been used. Antimicrobial activity on cellulose fibers, such as silver compounds have been widely used because it has a broad spectrum of antibacterial activity showed low toxicity against mammalian cells. To improve the antibacterial properties of the cellulose material, application of silver nanoparticles on bacterial cellulose and bacterial cellulose - chitosan composite could be conducted. At the nanoscale, particles of silver have a physical, chemical, and biological properties, as well as antibacterial activity (Zhong and Xia, 2008). Several studies reveal the inhibitory mechanism of silver nanoparticles on bacteria. The mechanism is assumed that the high silver affinity for sulfur and phosphorus are the key factors of the antibacterial effect. Proteins in the cell membrane of bacteria containing sulfur were plentiful, silver 
nanoparticles can react with sulfur-containing amino acids within or outside the membrane that will have an impact on the survival of bacteria (Zhang et al., 2011)

Silver nanoparticles have a good antibacterial ability due to large surface area which allows excellent contact with microorganisms. During the diffusion process, silver nanoparticles approach the bacterial cell membrane and penetrate into the bacteria. Particle monovalent silver ions $\left(\mathrm{Ag}^{+}\right)$cations capable of replacing hydrogen $\left(\mathrm{H}^{+}\right)$from the thiol groups of proteins, decrease membrane permeability, and ultimately cause cell death. Monovalent silver reaction with sulfhydryl compounds produce S-Ag clusters and are more stable on the surface of bacterial cells (Brudnerotto et al., 2001). Morphological changes that occurred in the $E$. coli after the treatment with silver nanoparticles could be seen using TEM analysis. The bacteria were not given the external morphology of the silver nanoparticles showed a normal form, but silver ions on E. coli for 2 hours showed serious damage to the cell wall. The E.coli cells showed aberrant morphology, cell walls have cracks and breaks (Zhang et al., 2011).

Based on the background, problems in this study include: the effect of the use of rice waste water to the successful formation of bacterial cellulose by Acetobacter xylinum, the effect of adding chitosan and glycerol as a plasticizer to biomaterial characteristics, the successful preparation of silver nanoparticles, as well as the effect of the application silver nanoparticles to antibacterial properties of bacterial celluloses and their composites. This study aims to utilize rice waste water in the formation of bacterial cellulose by Acetobacter xylinum, to study the effect of chitosan and glycerol as a plasticizer to the composite biomaterial characteristics, to prepare and deposit of silver nanoparticles, and to study the effect of the application of the silver nanoparticles toward the properties of the bacterial celluloses and their composites.

\section{METHODS}

The tools which are used in this research, including SEM JEOL JSM T300, FT-IR Shimadzu models prestige 21, Universal Testing Machine Zwick Z 0.5, Dumb Bell Ltd. Japan Saitama Cutter SOL-100, MT-365 Mitotuyo dial Thickness Gage 2046F, XRD instrument, UV-Vis instruments, Particle Size Analyzer, oven Memmert BE-500, autoclaves, digital balance Mettler Toledo BV, Fine Coat Ion Sputter JGC models 1100, pH sticks Merck®, wrapping paper, hot plate, thermometer, magnetic stirrer, and glasswares. The materials which are used in this study include rice waste water, chitosan, urea, glacial acetic acid, glycerol, silica gel, glucose, rubber, aquades, $\mathrm{NaOH}, \mathrm{HCl}$, and 
Acetobacter xylinum, Staphylococcus aureus, Escherichia coli, and the yeast of Candida albicans which are obtained from the Agricultural Technology, Gadjah Mada University, Yogyakarta, Indonesia.

Stage of the research is as follows: preparation of bacterial cellulose from rice water media, preparation of composite bacterial cellulose - chitosan composite $(\mathrm{CCh})$ by immersion method of bacterial cellulose in a solution of $2 \%$ chitosan, preparation of the bacterial cellulose - glycerol composite (CG) with a concentration of $0.5 \%$ glycerol solution, preparation of bacterial cellulose - chitosan composite with the addition of plasticizers such as glycerol solution $0.5 \%(\mathrm{CGCh})$, preparation of silver nanoparticles by reduction method using trisodium citrate, characterization of silver nanoparticles by UV Visible Absorption spectrophotometry and Particle Size Analyzer, and deposition of silver nanoparticles on the bacterial celluloses and theirs composite. The characterization of physical and chemical properties of bacterial celluloses and theirs composite material deposited silver nanoparticle including determination of functional groups by IR, mechanical properties such as a strong break, elongation at break and Young's modulus by tensile tester, surface observation by Scanning Electron Microscopy (SEM), and antibacterial activity test by diffusion method.

\section{Preparation the bacterial celluloses from rice waste water and theirs composites}

One kilogram of rice was washed with distilled water as much as 1 liter $(1: 1)$, then drained or filtered water with filter paper and placed in a container (bowl). The material is referred to as the rice waste water. Twenty grams of sucrose, 1.0 gram of urea, and 1.0 gram glycerol were mixed in $200 \mathrm{~mL}$ of rice waste water. The rice waste water was poured into Erlenmeyer that has been equipped with a magnetic stirrer, then stirred until dissolved. When the $\mathrm{pH}$ of the mixture solution was ranged between $5-6$, the mixture was acidified by addition of glacial acetic acid to a $\mathrm{pH}$ range from $3-4$. Subsequently the mixture was cooled briefly and then poured in a warm state into a tray that has been sterilized and cooled to room temperature. After chilling, the mixture was added $40 \mathrm{~mL}$ of Acetobacter xylinum and was fermented for 7 - 14 days at room temperature. After 7 - 14 days, the pellicle layer was taken and washed several times with tap water, then with distilled water, then with hot water, then this pellicle layer was weighed. Then a solution of $2 \%$ chitosan with deacetylation degree of $73.78 \%$ was poured onto the pellicle layer and dried in an oven with a temperature between $37-40{ }^{\circ} \mathrm{C}$. The bacterial cellulose and its composites were ready to be characterized. 


\section{Preparation and application silver nanoparticle}

Preparation of silver nanoparticles carried out by chemical reduction method. This method uses a solution of $\mathrm{AgNO}_{3}$ as an oxidator and a solution of trisodium citrate as a reducing agent. A total of $100 \mathrm{~mL} \mathrm{AgNO}_{3} 10^{-3} \mathrm{M}$ and 0.5 grams of PVA in the three-neck flask is then heated to a temperature of $90{ }^{\circ} \mathrm{C}$ while stirring using a magnetic stirrer. PVA (polyvinyl alcohol) is used as a stabilizer of colloidal silver. The PVA is used to make colloidal silver is not formed rapidly changing and unstable. The $10 \%$ of trisodium citrate solution is added dropwise. When the solution has reached a temperature of $90{ }^{\circ} \mathrm{C}$, dripping performed until the solution turns yellow. The solution which has turned yellow was flowing nitrogen gas and the heating is stopped. The nitrogen gas is used to remove oxygen flows resulting from the reduction process and to make cool the solution. Expulsion of oxygen gas intended that colloidal silver is not agglomerated and oxidized back. The measurement wavelength of maximum absorbance by using UV-Vis spectrophotometry performed in the range of $190-500 \mathrm{~nm}$. The application of silver nanoparticles has been done by inserting the cellulose in a glass beaker containing silver nanoparticles up entirely submerged. Cellulose membrane incorporated into the shaker at a speed of $145 \mathrm{rpm}$ for 60 minutes. Then the cellulose membrane was dried with a temperature of $50{ }^{\circ} \mathrm{C}$.

\section{Characterization of functional group}

This analysis used a set of tool FTIR - ATR and performed at the Leather Technology Academy, Yogyakarta, Indonesia. A thin layer is clamped in place and then put the device in the direction of the infrared beam. The result will be recorded onto paper in the form of the intensity versus wave numbers.

\section{Characterization of surface morphological}

SEM image of bacterial cellulose and its composites was measured using SEM instrument. This test was performed in Laboratory at the Center for Borobudur Conservation Agency. Sample was cut in such a way, then was coated with ion coater apparatus for approximately 5 minutes before vacuum process. Sample was introduced into the electron gun. Then the sample was set with microstage to get the right focus and accelerate voltage detector sets, 20 kilo volts.

\section{Characterization of mechanical properties.}

The characterization of mechanical properties was performed in Laboratory of Biotechnology, Faculty of Agricultural Technology, UGM. The dried sample material was cut to the size of $11 \mathrm{~cm} \times 2 \mathrm{~cm}$. The bacterial celluose specimen and its composites 
specimen were put in dumbble cutting. Then the sample was measured with a micrometer Mitutoyo thickness and both sides of the cutting result was attached to a Universal Testing Machine. Power and panel were in the on position. Then the device is turned on and set to the test speed $=10 \mathrm{~mm} / \mathrm{min}$ and the specimens were observed to drop out, the test was stopped when the specimen was broken. Data obtained in the form of percent elongation, tensile strength, and F max.

\section{Characterization of antibacterial activity}

The antimicrobial activity against bacteria was undertaken with the following stages. Sterilization of tools and media. Staphylococcus aureus isolates ATCC 25923 was rejuvenated by microbial inoculation on medium NA and incubated for 24 hours at room temperature. S. aureus ATCC 25923 was inoculated into NB medium in bottles and incubated using the incubator temperature $37{ }^{\circ} \mathrm{C}$. After 24 hours, optical density of $S$. aureus ATCC 25923 in NB media was measured. If optical density (OD) of S. aureus ATCC 25923 in NB media has shown 1, then $100 \mathrm{~mL}$ cultures of $S$. aureus inoculated into solid media NA in petridish. Optical density 1 showed that the number of microbes in 1 $\mathrm{mL}$ of culture is as much as $1 \times 10^{8}$. The microbial inoculation was done on solid media in petridish using the spread plate method. $100 \mathrm{~mL}$ of liquid culture in NB media was moved in petridish aseptically using a pipette tip. The bacterial cellulose and its composites were placed on the culture of microbes in the petridish, then incubated at $37{ }^{\circ} \mathrm{C}$. Inhibition zone of the bacterial cellulose and its composites against microbes was observed and measured using calipers for 24 hours. Clear zone around the bacterial cellulose and its composites showed inhibition activity of the bacterial cellulose toward microbial growth. The increasing diameter of the clear zone showed antibacterial activity.

\section{DISCUSSION}

\section{The physical properties of the bacterial celluloses and theirs composites}

The cellulose is produced as many as four types of the bacterial cellulose $(\mathrm{C})$, the bacterial cellulose - glycerol (CG), the bacterial cellulose - chitosan $(\mathrm{CCh})$, the bacterial cellulose - glycerol - chitosan (CGCh). The physical properties of the bacterial cellulose from rice waste water are summarized in Table 1.

Table 1 shows the physical properties of the bacterial celluloses and theirs composites. The physical properties of the bacterial cellulose products without and with the addition of glycerol ( $\mathrm{C}$ and $\mathrm{CG}$ ) have the same color, transparency, smell, and texture. The bacterial cellulose - chitosan - glycerol composites (CChGs) have a yellow color and 
acidic odor. Odor which is generated also due to the solvent used in the preparation of chitosan solution. The bacterial cellulose is capable of binding water (Zhong and Xia, 2008). Chitosan is able to enter into the pores of the microbial cellulose and the bacterial cellulose surface coating so that the water that was in the air can not enter. Another possibility, because hydrogen bond in chitosan interacts with the $-\mathrm{OH}$ group on the cellulose so that water in the environment can not bind hydrogen, but not completely dried cellulose chitosan glycerol because the water is still able to interact with the chitosan via hydrogen bonds (Gadag and Shetty, 2006).

Table 1. Physical properties of the bacterial cellulose from rice waste water.

\begin{tabular}{llll}
\hline Parameter & The C & The CG & The CGCh \\
\hline Wet Mass & 11.254 gram & 15.579 gram & 14.913 gram \\
Dry Mass & 0.347 gram & 0.386 gram & 2.500 gram \\
\% Wet Yield & $9.378 \%$ & $12.982 \%$ & $12.427 \%$ \\
\% Dry Yield & $3.070 \%$ & $2.480 \%$ & $16.769 \%$ \\
Transparency & Transparan & Transparan & Transparan \\
Color & white & White & brown yellow \\
Odor & Not odor & Not odor & Acid \\
Dry Texture & Tough, dry & Tough, dry & Tough, dry \\
\hline
\end{tabular}

\section{The physical properties of silver nanoparticle}

The maximum wavelength of $\mathrm{AgNO}_{3}$ solution was at $216.20 \mathrm{~nm}$ region. The spectrum measurement results of colloidal silver nanoparticles showed two largest peaks at a wavelength of $423.40 \mathrm{~nm}$ and the maximum at $225.80 \mathrm{~nm}$. The maximum peak at wavelength of $225.80 \mathrm{~nm}$ in the spectrum of colloidal silver nanoparticles showed that there is still a $\mathrm{AgNO}_{3}$ compound, it is possible because of the interaction between $\mathrm{Ag}$ with $\mathrm{H}^{+}$as a reaction product formed $\mathrm{AgNO}_{3}$ solution. A maximum peak at wavelength of $423.40 \mathrm{~nm}$ indicated the presence of silver nanoparticles (Lina et al., 2011 and Brugnerotto et al., 2001). Based on Particle Size Analyzer results indicated that the reduction of silver nitrate solution with a reducing agent of trisodium citrate has a median particle size of 74.8 $\mathrm{nm}$ and modus of $61.8 \mathrm{~nm}$.

\section{The functional group of the bacterial cellulose}

Analysis of the functional groups were performed using FTIR-ATR instrument. Data analysis of functional groups in the form of IR spectra is shown in Figure 1. The IR spectrum shows absorption of $-\mathrm{OH}$ groups of the $\mathrm{CChN}$ is lower than $-\mathrm{OH}$ group of the CG. The IR spectrum of the CGCh shows typical absorption band for cellulosic functional groups and functinal group $-\mathrm{NH}_{2}$. The functional group of the CGCh is almost the same as 
the functional groups of the CCh. Based on the IR spectrum interpretation, the functional group of the bacterial cellulose and its composite are shown in Table 2.

Among the IR spectrum of the CGN, the CGN, the CChN, and the CGChN show the similar functional group. The interpretation result of the IR spectrum can be shown in Table 2.

Table 2. The functional group of the $\mathrm{CN}$ and the CGN.

\begin{tabular}{ccc}
\hline Samples & Wave number $\left(\mathrm{cm}^{-1}\right)$ & Functional Group \\
\hline The CN & 3339.31 & OH \\
& $2900-3000$ and 424.08 & C-H \\
& $1200-1031.53$ & C-O glycosidic \\
The CGN & $1475-1450$ & Pyranose \\
& 3340.98 & OH \\
& $2900-3000$ dan $1450-1375$ & C-H \\
& $1193.95,1105.91$ dan & C-O glycocidic \\
The CChN & 1030.81 & Pyranose \\
& $1500-1475$ & OH, NH $H_{2}$ \\
& 3339.76 & C-H \\
& $2900-3000$ and 1465 & C-H amine \\
The CGChN & $1300-1250$ & C-O glycosidic \\
& $1194.28-1031.18$ & Pyranose \\
& $1500-1475$ & $-O H, ~ N H_{2}$, \\
& 3336.04 & C-H amine \\
& 1238.19 & C-O Glycosidic \\
& $1194.41-1031.77$ & C-H \\
& $2900-3000$ and 1465 & Pyranose \\
\end{tabular}

The IR spectra of CGCh shows uptake in the area of $3336.04 \mathrm{~cm}^{-1}$ which is the absorption of $\mathrm{OH}$ and $\mathrm{NH}_{2}$ groups. Absorption bands at wave number 1194.41 to 1031.77 $\mathrm{cm}^{-1}$ indicate the presence of CO glycosidic, the presence of three sharp absorption band in the region and the absorption at $2900-3000 \mathrm{~cm}^{-1}$ indicate $\mathrm{CH}$ backed their uptake in wave numbers of $1465 \mathrm{~cm}^{-1}$. Uptake of aromatic groups indicate their absorption in the $1500-1475 \mathrm{~cm}^{-1}$, the aromatic group is a group piran. The -OH absorption band on the CGN showed its transmittance is smaller than the uptake $-\mathrm{OH}$ on the $\mathrm{C}$. The smaller the transmittance of the $\mathrm{OH}$, the greater the absorbance of $-\mathrm{OH}$, so the number of $\mathrm{OH}$ on the CGN is more than- $\mathrm{OH}$ on the $\mathrm{CN}$. The amount of hydrogen bonded can be seen from the wide absorption band. If the absorption band is broad, it shows the -OH hydrogen bonding. Based on the IR spectrum, it shows absorption band of -OH of the CGN is wider than the $\mathrm{CN}$. Thus, it indicates that the addition of glycerol will increase the number of hydrogen bonds on the CN. The FTIR spectrum shows that the $-\mathrm{OH}$ absorption of the CGChN is sharper than the $-\mathrm{OH}$ absorption of the $\mathrm{CChN}$. 

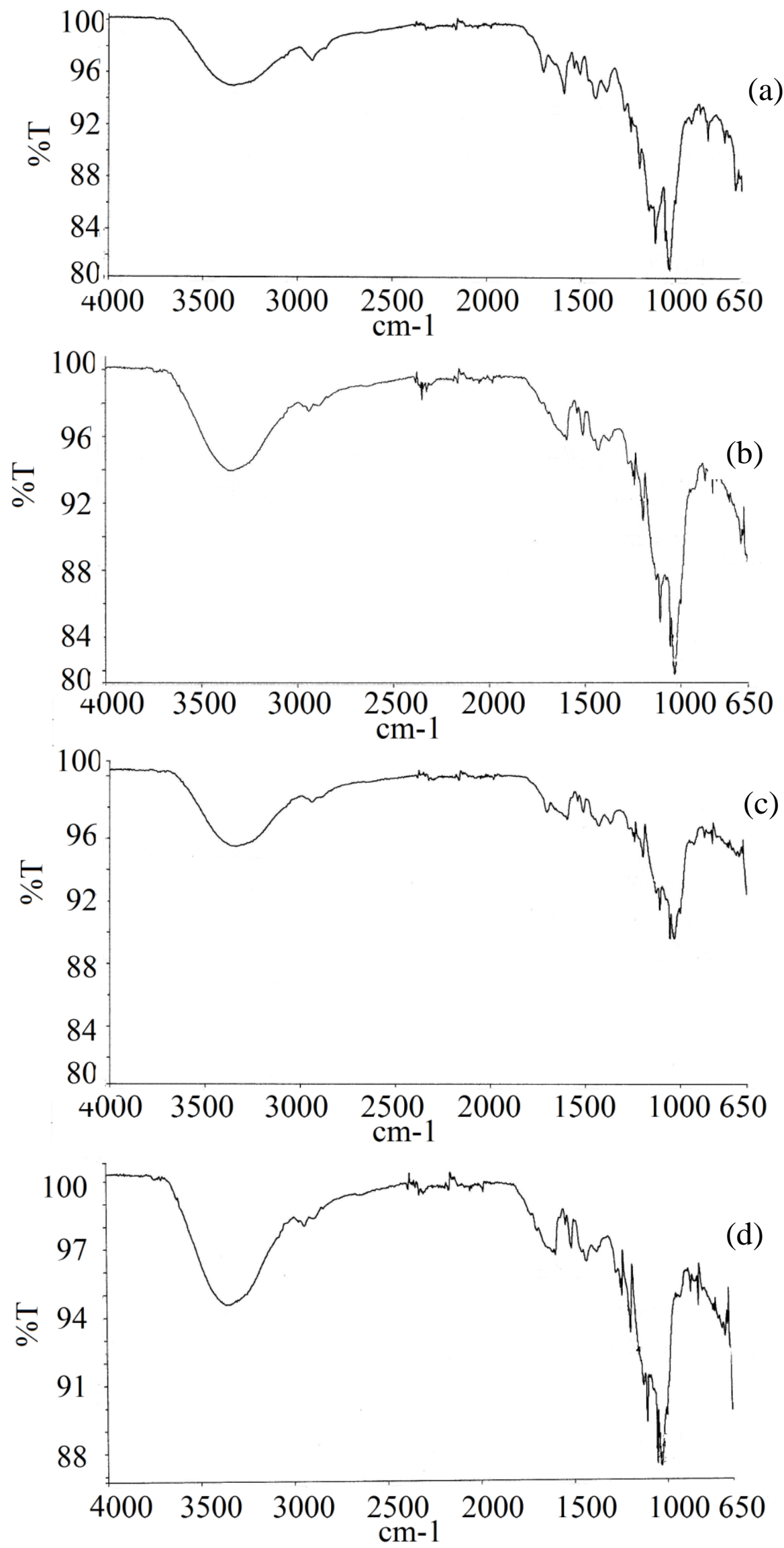

Figure 1. The IR spectrum of (a). the $\mathrm{CN}$, (b). the CGN, (c). the $\mathrm{CChN}$, and (d). The CGChN. 
The addition of glycerol and chitosan on the bacterial cellulose increase the number of $-\mathrm{OH}$ and amine groups in the cellulose. The addition of glycerol to the bacterial cellulose - chitosan causes an increasing of hydrogen bonds in the bacterial cellulose, as shown by the -OH absorption band in the bacterial cellulose -chitosan - glycerol (Zhong and Xia, 2008). Results of functional groups by FTIR analysis showed aromatic ring and vibration of amino group is characteristic of chitosan (Brugnerotto et al., 2001). This characteristic absorptions alleged overlap with absorption aromatic ring, because the cellulose and chitosan has an aromatic ring.

\section{The Mechanical Properties of The Bacterial Cellulose}

Based on the results of mechanical tests four samples of cellulose, the data amounted strength at break, elongation at break and Young's modulus of microbial cellulose, cellulose glycerol, cellulose selulsa chitosan and chitosan glycerol deposited silver nanoparticles can be summarized in Table 3.

Table 3. The mechanical properties of the bacterial cellulose which is deposit silver nanoparticle.

\begin{tabular}{lccc}
\hline \multicolumn{1}{c}{ Samples } & Strength at break $(\mathrm{MPa})$ & Elongation at break $(\%)$ & Modulus Young (MPa) \\
\hline The CN & 54.878 & 20.3790 & 628.25 \\
The CGN & 87.560 & 9.7947 & 1268.30 \\
The CChN & 14.772 & 4.7842 & 660.55 \\
The CGChN & 7.9582 & 7.7829 & 249.18 \\
\hline
\end{tabular}

Based on the Table 3, the CGN has the highest Young's modulus of 1268.3 MPa, and the strength at break of $87.560 \mathrm{MPa}$. The $\mathrm{CN}$ has the highest elongation at break of $20.379 \%$. Thus, the CGN has the highest load bearing strength. This is likely due to the initial structure of cellulose has a high crystallinity and addition of glycerol as internal plasticizer can cause interacting between $-\mathrm{OH}$ of the cellulose and $-\mathrm{OH}$ of glycerol in forming hydrogen bonds so that the CGN has stronger structure than the $\mathrm{CN}$ (Yunos and Rahman, 2001). The addition of glycerol will generate interaction between -OH of cellulose and $-\mathrm{OH}$ of glycerol through hydrogen bonding or dipole-dipole interactions (Klaykruayat et al., 2010 and Kaushish, 2010). The more hydrogen bonds and high crystallinity of the CGN cause it is able to withstand loads better than the CN. The correlation between the increasing in hydrogen bonding and the tensile strength proved that the increasing of hydrogen bonds will increase the tensile strength (Zhong and Xia, 2008; Zhang et al., 2011; Liu et al., 2009; and Tien, 2010). Another possibility is the addition of glycerol can increase molecular mass of the CGN. A polyethylene plastic which has a 
higher molecular mass shows the higher tensile strength than the lower molecular mass (Brown, 2001). This may be a possibility when the glycerol was added, there was an increase in the molecular mass of the cellulose so that a higher tensile strength of the CGN than the $\mathrm{CN}$.

The addition of chitosan turns down the strength at break of the $\mathrm{CN}$. The reduction of strength at break of the $\mathrm{CChN}$ could be caused the chitosan is a polymer with amorphous structure, so the addition of chitosan to the $\mathrm{CN}$ will make the decreasing of crystallinity of the CChN. The decreasing of the crystallinity of cellulose decreases the load bearing strength of the $\mathrm{CChN}$. A material is structurally strong because of high crystallinity of a resistance to higher pressure, than the materials whose structure is irregular and gives a lot of space around it (Liu et al., 2009). The addition to the amorphous nature of the material that has high crystallinity will make crystalline compound initially be semi-crystalline so many empty spaces that appeared causes of force against the pressure to be reduced. The addition of the chitosan decreases elongation at break significantly. Film corn starch occurs intermolecular bonds form hydrogen bonds (Morones et al., 2005). This bond increases tensile strength but decreases elongation. This is caused by hydrogen bonding in the formation of a crystal structure, that is rigid and strong so that the elasticity of the material will decrease. The reason is based on glycerol effect by disrupting intermolecular bonds in cellulose has a less rigid structure. Conversely, if the intermolecular bonds in cellulose more and more due to the addition of chitosan, it can be said that the elongation of the cellulose will decrease (Rechia et al., 2010).

\section{The SEM Photograph of The Bacterial Cellulose}

Figure 2 shows the SEM photos of the bacterial celluloses and theirs composite which are deposited nanoparticles silver. The photos are enough to prove the difference between addition of chitosan and addition of glycerol on the cellulose. This proves that chitosan is capable on coating the entire surface of the bacterial cellulose. The SEM results indicate that silver nanoparticles also successfully deposited on the bacterial cellulose from rice waste water. The suspected silver nanoparticles adsorbed on the bacterial cellulose. Interactions between the bacterial cellulose and silver nanoparticles are chemical adsorption which occurs through chemical bonds to form a covalent bond between - $\mathrm{OH}$ groups on microbial cellulose with Ag in the silver nanoparticles. Figure 2 shows the SEM photos of the bacterial celluloses and theirs composite which are deposited nanoparticles silver. 

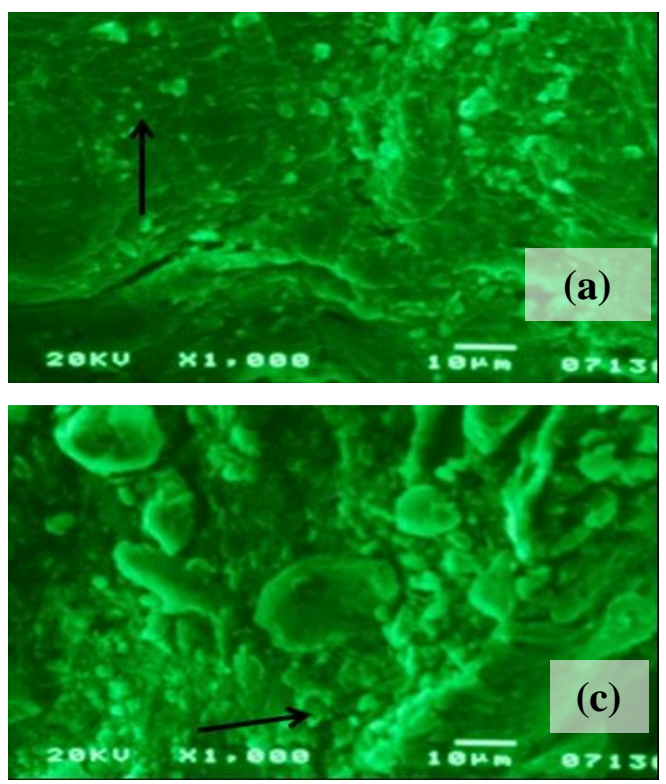
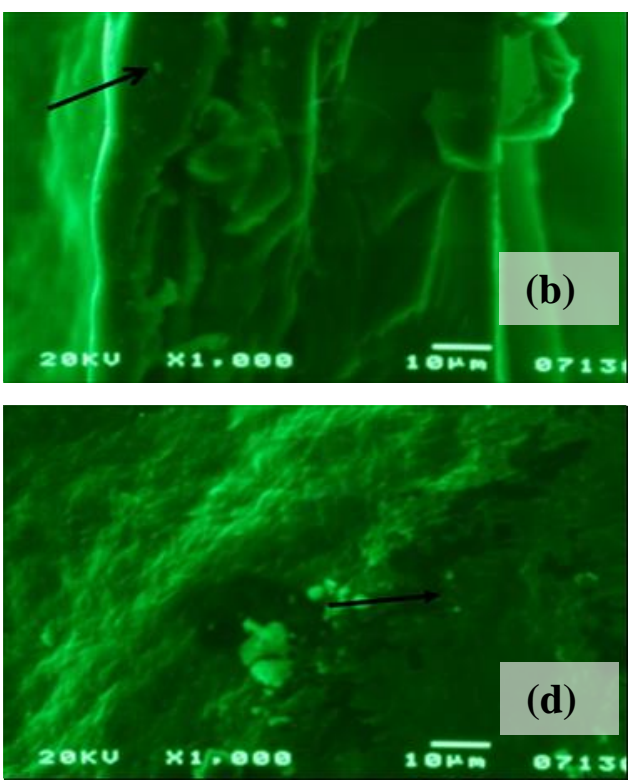

Figure 2. The SEM photos of (a). the CN; (b). the CGN; (c). the CChN; (d). the CGChN.

\section{The antibacterial activity of the bacterial cellulose and its composite}

Parameters of antimicrobial activity is apparent diameter of the clear zone around the sample. A clear zone around the sample is formed because no microbes that can be grown on the spot due to the antimicrobial activity of a compound in the sample. The wider of the clear zone diameter indicates that the samples more effectively inhibit the growth of microbes.

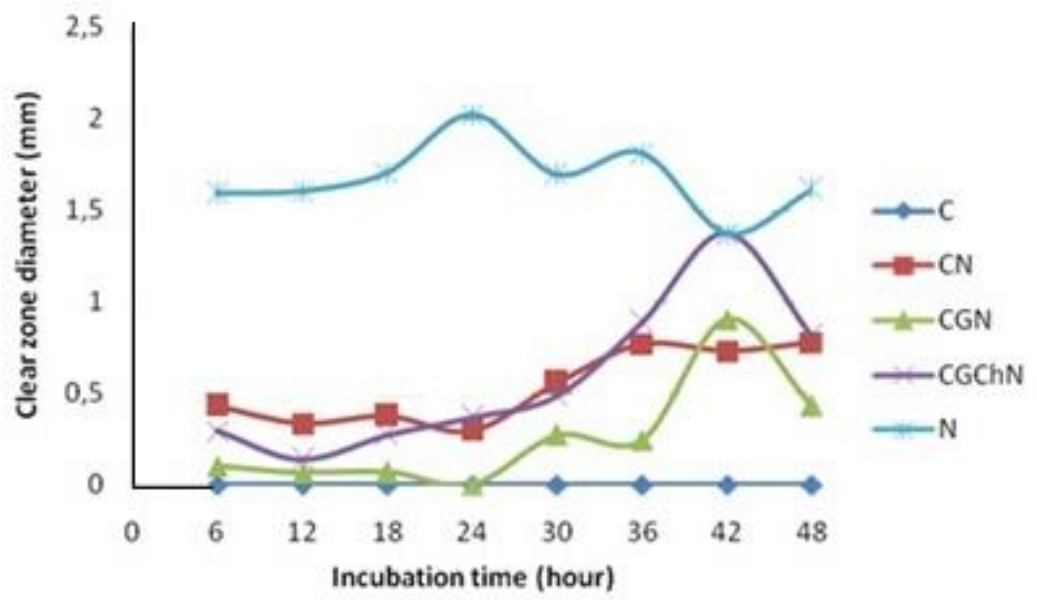

Figure 3. The Clear zone diameter of the bacterial cellulose and its composite against Staphylococcus aureus ATCC 25923.

Observation zone of inhibition was conducted for every 6 hours to know an antimicrobial activity. Figure 3 shows that the samples against Staphylococcus aureus ATCC 25923 have shown inhibition zone on the observation of the first 6 hours of incubation, although still very narrow (except on pure cellulose samples). The CGN and 
the CGChN show inhibition zone diameter which began to decline after incubation for 42 hours. The CGChN has largest inhibition zone, while the $\mathrm{C}$ has the lowest inhibition zones. ANOVA statistical test among sample types which were used against Staphylococcus aureus ATCC 25923 shows that there are significant differences among the types of samples. ANOVA statistical test among incubation time of Staphylococcus aureus ATCC 25923 shows a significance value of $0.744(\mathrm{P}>0.05)$, meaning there is no significant difference between the time of incubation of the samples against bacteria Staphylococcus aureus ATCC 25923. Figure 4 shows that the testing of samples against yeast Candida albicans ATCC 10231 has shown inhibition zone in the first 12 hours of observation. The lowest antimicrobial on testing with Candida albicans is the $\mathrm{CN}$, then the sample $\mathrm{C}$ and CGChN, however the highest antifungal is indicated by the CGN sample The highest inhibition is achieved at 18 hours incubation time.

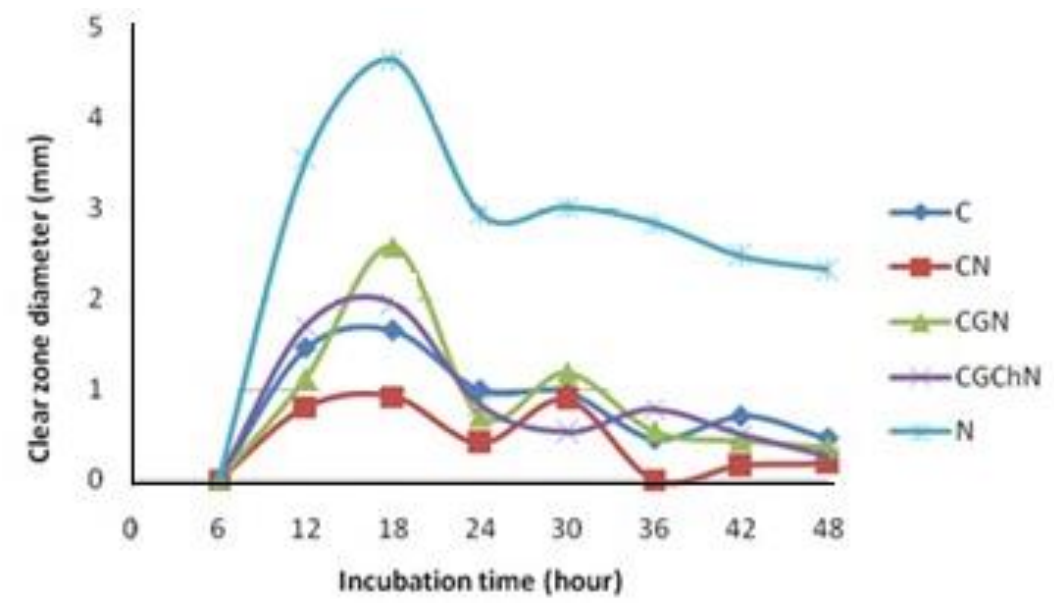

Figure 4. The Clear zone diameter of the bacterial cellulose and its composite against Candida albicans ATCC 10231.

The samples have a inhibition of microbial activity against Candida albicans yeast larger than a inhibition against Staphylococcus aureus. Differences in the effectiveness of this inhibition may be due to the structure of the bacterial cell. The peptidoglycan of $S$. aureus is a thick layer, serves as protection of antibacterial agents such as antibiotics, toxins, chemicals, and degradative enzymes. Candida albicans cell wall is complex and dynamic with a $100-400 \mathrm{~nm}$ thick. The outer layer of the cell wall of $C$. albicans consist of mannoprotein. Mannoprotein represents $30-40 \%$ of total cell wall polysaccharides and determines the nature of the cell surface. C. albicans cell wall also contains sterols which plays an important role as targets antimycotic and possibilities are the workings of enzymes that play a role in cell wall synthesis. It can be concluded that the mannoprotein 
and sterols in the cell wall of Candida albicans causes high antimicrobial activity on the samples against $C$. albicans.

Peptidoglycan in Staphylococcus aureus has teikoic acid, a polyalcohol which is linked by phosphodiester bonds and usually has other sugars bonded with it. The teikoic acids are negatively charged (having - $\mathrm{COOH}$ or - $\mathrm{COO}$ - group and phosphate group), thus providing a negative charge on the surface of bacterial cells. Silver nanoparticles have a positive charge $\left(\mathrm{Ag}^{+}\right)$, making it easier to bind to the negatively charged surface of the bacteria (Kim et al., 2007; Feng et al., 2000; and Jung et al., 2008). The -COO-group will bind with $\mathrm{Ag}^{+}$. Then $\mathrm{Ag}^{+}$will affect the proteins in the cell membrane. Therefore, the silver nanoparticles react faster on the bacteria $S$. aureus compared with yeast $C$. albicans. It marked only with a time of 6 hours has seen the diameter of inhibition zone in S. aureus bacteria.

Candida albicans cell wall has a lot of mannoprotein which has positively charged amine groups. The positive charge on the surface of $C$. albicans is a little slow to react to the silver nanoparticles which were also charged positive. This is due to the tendency of the same charge for this slow reaction. The reaction is marked by inhibition zone in yeast C. albicans after 12 hours of incubation. The silver nanoparticles will affect the sulfhydryl groups on the protein surface (mannoprotein). The number of mannoprotein which is influenced by silver nanoparticles, then the resulting optimal inhibition.

The antibacterial activity of the cellulose samples which are deposited silver nanoparticles against E.coli ATCC 25922 are shown in Table 4. The antibacterial activity test of all samples shows positive results. The largest clear zone is given by the CGN, then the CChN, the latter the $\mathrm{CN}$ and the CGChN. Based on these results, the CGN is the most effective against the E. coli ATCC 25922 compared to the three other types of cellulose.

Table 4. The antibacterial activity of the bacterial cellulose and its composite against E.coli ATCC25922.

\begin{tabular}{lc}
\multicolumn{1}{c}{ Samples } & The Diameter of Clear Zone \\
\hline The CN & $1 \mathrm{~mm}$ \\
The CGN & $1.66 \mathrm{~mm}$ \\
The CChN & $1.16 \mathrm{~mm}$ \\
The CGChN & $1 \mathrm{~mm}$ \\
\hline
\end{tabular}

The clear zone diameter of the $\mathrm{CChN}$ is greater than the $\mathrm{CN}$, this is caused by the regular structure of the $\mathrm{CChN}$. Therefore, it is difficult for the silver nanoparticles to interact electrostatically with functional groups of the $\mathrm{CChN}$ because of steric hindrance. The composition of the cellulose with chitosan will change cellulose structure. Chitosan is a polymer amorphous so that if the chitosan is composited with cellulose, the crystallinity of the cellulose bacteria into 
decline with the addition of chitosan. Composite structures are more amorphous and the silver nanoparticles easier attack to functional groups by electrostatic interaction. The CGChN samples showed a positive antibacterial against E. coli ATCC 25922 and has a inhibition diameter of 1 $\mathrm{mm}$. The CGChN has physical properties similar to the $\mathrm{CChN}$ but the CGChN contains plasticizer glycerol. The CGN molecular structure is shown in Figure 5. Based on these interactions seem that the CGN has a structure steric bulk and a lot of obstacles causing the silver nanoparticles is difficult to interact electrostatically with functional groups such as $-\mathrm{OH}$ and $\mathrm{NH}_{2}$. (Tien, 2010; Smith et al., 1982; Helander et al., 2003; and Desi, 2006). If the silver nanoparticles is difficult to interact with the functional groups, the antibacterial activity will be low due to at least silver nanoparticles deposited on the CGChN. However, based on Figure 3 and 4, silver nanoparticles showed the highest antibacterial activity, this is in accordance with the literature that silver nanoparticles act as an antibacterial (Rai and Bai, 2010; Agus and Sri, 2010).

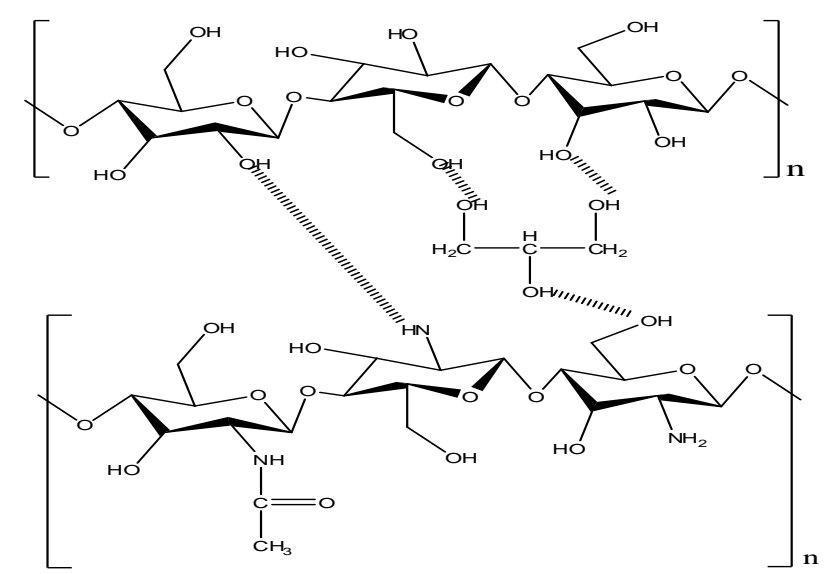

Figure 5. Interaction among glycerol, chitosan, and cellulose.

\section{CONCLUSION}

Based on the results of the research and the discussion, it can be concluded that the rice waste water can be used as a medium for bacterial growth in the formation of the bacterial cellulose. The bacterial cellulose and the bacterial cellulose - glycerol composite, which are deposited silver nanoparticles, have functional groups $-\mathrm{OH}, \mathrm{CH}, \mathrm{CO}$ glycosidic and pyranose. The bacterial cellulose - chitosan $(\mathrm{CCh})$ and the bacterial cellulose glycerol - chitosan (CGCh) have functional groups $-\mathrm{OH}, \mathrm{NH}_{2}, \mathrm{CN}$ amide, $\mathrm{CO}$ glycosidic, $\mathrm{CH}$, and pyranose. The bacterial cellulose - glycerol, which is deposited silver nanoparticles (CGN), has a strength at break of $1268.3 \mathrm{MPa}$. The CGN has the highest Young's modulus. The CNs have an elongation at break of $20.379 \%$. The SEM photos of the $\mathrm{CN}$ shows that the silver nanoparticles has been deposited on the surface of bacterial cellulose. The antibacterial test results shows an inhibitory effect of the $\mathrm{CN}$, the $\mathrm{CChN}$, 
and the CGChN against the growth of S. aureus, E. coli, and C.albicans. The CGChNs provide the highest antimicrobial activity against Staphylococcus aureus ATCC 25923. The CGNs provide the highest antimicrobial activity against $E$. coli ATCC 25922 and the yeast Candida albicans ATCC 10231.

\section{ACKNOWLEDGEMENT}

Acknowledgements submitted to the Ministry of Research and Technology of the Republic of Indonesia, which has provided financial support through the Research Incentive SINas 2014.

\section{REFERENCES}

Agus, H., and Sri, B. H, 2010, Aplikasi Nanopartikel Perak pada Serat Katun sebagai Produk jadi Tekstil Antimikroba, Jurnal Kimia Indonesia, vol. 5, no. 1, pp. 1- 6.

Anicuta, S. G., Dobre, L., Stroesc,a M., and Jipa, I., 2010, Fourier Transform Infrared (FTIR) Spectroscopy for Characterization of Antimicrobial Films Containing Chitosan, Analele UniversităNiii din Oradea Fascicula: Ecotoxicologie, Zootehnie şi Tehnologii de Industrie Alimentară, pp. 1234-1240.

Baker, C. V., Pradhan, L. P., Pochan, D. J., and Shah, S. I., 2005, Synthesis and Antibacterial Properties of Silver Nanoparticles, Journal Nanoscience Nanotechnology, vol. 5, pp. 244-249.

Brown, M. E., 2001, Introduction of Thermal Analysis : Techniques and Applications 2nd Edition (Dordrecht : Kluwer Academic Publishers).

Brugnerotto, J., Lizardi, J., Goycoolea, F. M., Arguella-Monal, W., Desbrieres, J., and Rinaudo, M, 2001, An Infrared Investigation in Relation with Chitin and Chitosan Characterization, Polymer, vol. 42, no. 8, pp. 3569-3580.

Ciechańska, D., 2004, Multifunctional Bacterial Cellulose/Chitosan Composite Materials for Medical Application, Fiber \& Textiles in Eastern Europe, vol. 12, pp. 69-72.

Desi, A. Y., 2006, Hubungan antara Aktivitas Antibakteri Kitosan dan Ciri Permukaan Dinding Sel Bakteri, Thesis, IPB.

Fang, J. C., Zhong, R., and Mu, R., 2005, The Study of Deposited Silver Particulate Films by Simple Method for Efficient SERS, Chemical Physics Letters, vol. 401, no. 1, pp. 271-275.

Feng, Q. L., Wu, J., Chen, G. Q., Cui, F. Z., Kim, T. N., and Kim, J. O., 2000, A Mechanistic Study of The Antibacterial Effect of Silver Ions on Escherichia coli and Staphylococcus aureus, Journal of Biomedical Material Research, vol. 52, no. 4 , pp. 662-668.

Gadag and Shetty, 2006, Engineering Chemistry, New Delhi : International Publishing House Pvt. Ltd. 
Helander, I. M., Nurniaho, E. L., Ahvenainen, R., Rhoades, J., and Roller, S., 2001, Chitosan Disrupts The Barrier Properties of The Outer Membrane of Gramnegative Bacteria, Journal of Food Microbiology, vol. 7, no. 1, pp. 235-244.

Heru, P. and Eli, R., 2010, Pembuatan Bioplastik dari Limbah Rumah Tangga sebagai Bahan Edible Film Ramah Lingkungan, Laporan Penelitian, Yogyakarta : UNY

Hoenich, N., 2006., Cellulose for Medical Applications: Past, Present, and Future, BioResources, vol. 1, no. 2, pp. 270-280.

Jung, K. W., Koo, H. C., Kim, K. W., Shin, S., Kim, S. H., and Park, Y. H., 2008, Antibacterial Activity and Mechanism of Action of the Silver Ion in Staphylococcus aureus and Escherichia coli, Journal American Society for Microbiology, vol. 74, no. 7, pp. 2171-2178.

Kaushish, J. P., 2010, Manufacturing Process $2^{\text {nd }}$ Edition, New Delhi : PHI Learning Private Limited.

Kim, Jung Sung, Eunye Kuk, Kyeong Nam Yu, Jong-Ho Kim, Sung Jin Park, Hu Jang Lee, So Hyun Kim, Young Kyung Park, Cheol-Yong Hwang, Yong-Kwon Kim, YoonSik Lee, Dae Hong Jeong, and Myung-Haing Chao, 2007, Antimicrobial effects of silver nanoparticles, Nanotechnology, Biology and Medicine, vol. 3, no. 1, pp. 95101.

Klaykruayat, B., Siralertmukul, K., and Srikulkit, K., 2010, Chemical Modification of Chitosan with Cationic Hyperbranched Dendritic Polyamidoamine and Its Antimicrobial Activity on Cotton Fabric, Carbohydrate Polymers, vol. 80, no. 1, pp. 97-207.

Kuusipalo, J., Kaunisto, M., Laine, A., and Kellomaki, M., 2005, Chitosan as a Coating Additive in Paper and Paperboard, TAPPI Journal, vol. 4, no. 8, pp. 17-21.

Lina, F., Yue, Z., Jin, Z., and Guang, Y., 2011, Bacterial Cellulose for Skin Repair Materials, Biomedical Engineering - Frontiers and Challenges (Croatia : InTech).

Liu, X., Gao, G., Dong, L., Ye, G., and Gu, Y., 2009, Correlation between HydrogenBonding Interaction and Mechanical Properties of Polyimide Fibers, Polymer Advanced Technology, vol. 20, pp. 362-366.

Morones, J. R., Elechiguerra, J. L., Camacho, A., Holt, K., Kouri, J. B., Ramirez, J. T., and Yacaman, M. J., 2005, The Bactericidal Effect of Silver Nanoparticles, Nanotechnology, vol. 16, no. 1, pp. 2346.

Philips, G. O., and Williams, P. A., 2000, Handbook of Hydrocolloids, Cambridge : Woodhead Publishing Ltd.

Rai, R., and Bai, J. A., 2011, Nanoparticles and Their Potential Application as Antibacerials, Science Against Microbacterial Pathogens : Comunicating Current Research and Technological Advance, pp. 197-209.

Rechia, L. M., Morona, J. B., Zepon, K. M., Soldi, V., and Kanis, L. A., 2010, Mechanical properties and total hydroxycinnamic derivative release of starch/glycerol/Melissa officinalis extract films, Brazilian Journal of Pharmacy Science, vol. 46, no. 3, pp. 491-497.

Smith, P., Lemstra, P. J., and Pijpers, L. P. L., 1982, Tensile Strength of Highly Oriented Polyethylene. II. Effect of Molecular Weight Distribution, Journal of Polymer Physics Part B, vol. 20, no. 1, pp. 2229-2241. 
Tien, B., 2010, Modifying Cellulose to Create Protective Material for Firefighters, (http://cosmos.ucdavis.edu/archives/2010/cluster8/TIEN_Benjamin.pdf)

Yunos, M. B. Z., and Rahman, W. A., 2011, Effect of Glycerol on Performance Rice Straw/Starch Based Polymer, Journal of Applied Science, vol. 11(13), pp. 24562459.

Zhang, H., Deng, L., Yang, M., Min, S., Yang, L., and Zhu, L., 2011, Enhancing Effect of Glycerol on the Tensile Properties of Bombyx mori Cocoon Sericin Films, International Journal of Molecul Science, vol. 12(5), pp. 3170-3181.

Zhong, Q. P., and Xia, W. S., 2008, Physicochemical Properties of Edible and Preservative Films from Chitosan/Cassava Starch/Gelatin Blend Plasticized with Glycerol, Physicochemical Properties of Chitosan-Based Films Food Technology and Biotechnology, vol. 46(3), pp. 262-269. 